\title{
CONTEMPORARY AND FUTURE POTENTIAL GEOGRAPHIC DISTRIBUTION OF Cedrela fissilis Vell. UNDER CLIMATE CHANGE SCENARIOS
}

\author{
Silvane de Fátima Siqueira ${ }^{2}$, Pedro Higuchi ${ }^{3 *}$ and Ana Carolina da Silva ${ }^{3}(\mathbb{C}$
}

\author{
${ }^{1}$ Received on 23.04.2018 accepted for publication on 20.08.2019. \\ ${ }^{2}$ Universidade do Estado de Santa Catarina, Programa de Pós-Graduação em Engenharia Florestal, Lages, SC - Brasil. E-mail: \\ $<$ biosilvane@hotmail.com>. \\ ${ }^{3}$ Universidade do Estado de Santa Catarina, Departamento de Engenharia Florestal, Lages, SC - Brasil . E-mail: <higuchip@gmail.com > \\ and <carol_sil4@yahoo.com.br>. \\ *Corresponding author.
}

\begin{abstract}
The objective of the present work was to model the climate niche of Cedrela fissilis Vell. and to project the contemporary and future potential spatial distribution considering different climate change scenarios. Species occurrence data were obtained from the SpeciesLink and Global Biodiversity Information Facility (GBIF) databases. Altitude data, and 19 climate variables for both present and future conditions were obtained from the WorldClim database. The spatial prediction for the year 2070, considering an optimistic scenario (RCP 4.5) and a pessimistic one (RCP 8.5), was defined by Intergovernmental Panel on Climate Change (IPCC) regarding the concentration of greenhouse gases. The climate niche modeling was performed using the Maximum Entropy algorithm (MaxEnt). The results showed that C. fissilis has a wide geographic distribution, occurring in most South American countries. Its distribution showed a high correlation associated with the isothermal and precipitation variables in the humid month. In future scenarios, impacts on the climatic suitability of the areas in which the species occur, will not be spatially homogeneous. Indeed, reductions of about 47\% (RCP4.5) and 63\% (RCP8.5) are expected. It is recommended the creation and expansion of Conservation Units (CU) in areas that will remain climatically suitable for this species. The areas that will not have a favorable climate in the future should be considered strategic for genetic rescue and establishment of germplasm banks. Areas changing into a favorable climate should be considered as new areas of ecological and forestry interest.
\end{abstract}

Keywords: Maximum entropy; Climate niche modeling; Biogeography.

\section{DISTRIBUIÇÃO GEOGRÁFICA POTENCIAL CONTEMPORÂNEA E FUTURA DE Cedrela fissilis Vell. SOB CENARIOS DE MUDANÇAS CLIMATTICAS}

\begin{abstract}
RESUMO - O objetivo do presente trabalho foi modelar o nicho climático de Cedrela fissilis Vell. e realizar a projeção espacial potencial contemporânea e futura, considerando diferentes cenários de mudanças climáticas. Os dados de ocorrência da espécie foram obtidos a partir do banco de dados do SpeciesLink e GBIF. Os dados de altitude e 19 variáveis climáticas para as condições presente e futura foram obtidos por meio do banco de dados do WorldClim. Para a predição espacial futura no ano de 2070, considerou-se um cenário otimista (RCP 4.5) e outro pessimista (RCP 8.5), definido pelo IPCC em relação à concentração de gases causadores do efeito estufa. A modelagem do nicho climático foi realizada por meio do algoritmo de Máxima Entropia. Os resultados indicaram que C. fissilis possui ampla distribuição geográfica, ocorrendo na maioria dos países da América do Sul. Sua distribuição apresentou elevada correlação com as variáveis isotermalidade e precipitação no mês mais úmido. Em cenários futuros, os impactos sobre as áreas de adequabilidade climática da espécie não ocorrerão de forma espacialmente homogênea, esperando-se uma redução de cerca de 47\% (RCP4.5) e 63\% (RCP8.5). Recomenda-se a criação e expansão de Unidades de Conservação nas áreas que permanecerão com clima favorável à espécie. Nas áreas que não terão clima favorável no futuro, devem ser consideradas estratégicas para o resgate genético e a criação de bancos de germoplasma. As áreas que passarão a ter clima favorável no futuro devem ser consideradas como novas áreas de interesse ecológico e silvicultural.
\end{abstract}

Palavras-chave: Máxima entropia; Modelagem de nicho climático; Biogeografia.

Silf $(c)$ EY

Revista Árvore 2019;43(3):e430306 http://dx.doi.org/10.1590/1806-90882019000300006 


\section{INTRODUCTION}

The potential impacts that global climate changes will have on forest ecosystems are unequivocal (RANDIN et al., 2009), as all tree species present a specific climate niche in which they can develop more efficiently (THUILLER et al., 2009). Thus, climate change is expected to modify the floristic composition of forests.

This process occurs because the species demonstrate different requirements and tolerance regarding climate conditions, which are circumscribed within minimum and maximum limits (e.g., tolerance to temperature). Therefore, there is a "specific range" of favorable climatic conditions for each species (KÖCKE, 2015). According to Walther et al. (2002), these species can respond to climate change in one of four ways: migrating to regions with a climate similar to where they occur; becoming resilient, i.e. tolerating new climate conditions; evolving, which implies improving their resilience or ability to migrate; or simply being extinguished.

On account of future climate changes, it is inferred that tree species may be replaced in certain regions, so those species that do not adapt to the new environmental conditions will be replaced by the better-adapted ones (FIELD et al., 2014). At the same time, some species may have their area of occurrence reduced or even extinct due to being restricted to climatic refuges. On the other hand, other tree species may have their extent of occurrence (EOO) expanded when the new climatic conditions are more favorable (WEBBER and SCOTT, 2012).

In this context, it is of great importance to understand the impacts of potential future climate changes on the extent of occurrence of tree species, particularly those occurring in highly endangered forest formations, such as the Atlantic Forest. Among the tree species that occur in this biogeographic domain, Cedrela fissilis Vell. was selected because it is of substantial commercial and conservation interests in South America. As such, it has been widely investigated in ecological and environmental studies (GARCIA et al., 2011). Additionally, C. fissilis was prominent in Brazilian economy as one the most exported wood for timber in the 1970's, as well as it is suitable for a wide variety of uses - from musical instruments, carving works, fine furniture, and decorative interior design of boats to civil construction in general (CARVALHO, 2003). However, its worth as timber caused intense exploration of this species, which is now on the IUCN Red List of Threatened Species (INTERNATIONAL UNION FOR CONSERVATION OF NATURE AND NATURAL RESOURCES, 2013).

This work aimed to understand the geographic distribution patterns of $C$. fissilis, model its climate niche, and predict the potential distribution of this species affected by different scenarios of climate change due to its notable environmental, economic, and social importances.

\section{MATERIALS AND METHODS}

The data of geographical occurrence of $C$. fissilis were obtained from databases SpeciesLink; Centro de Referência em Informação Ambiental (CRIA) [Reference Center for Environmental Information] (CRIA, 2017), by consulting the following herbaria: ALCB, ASE, BCTw, BHCB, BOTU, CEN, CEPEC, CGMS, CNMT, CPAP, CRI, DVPR, EAC, EAFM, EFC, ESA, EVB, F, FPR-Colombia, FPS, FUEL, Funed-Pol, FURB, G, HAS, HbVirtFlBras, HCF, HDCF, HDJF, HEPH, HERBAM, HPAN, HPL, HUCPE, HUCS, HUEFS, HUEM, HUESB, HUFSJ, HUTO, HVASF, HVAT, IAC, INPA, IRAI, JPB, MAC, MBM, MBML-Herbario, MO, MPUC, NHMLondon-BOT, NY, PACA-AGP, RON, SinBiota, SJRP, SP, SPF, SPFw, SPSF, UB, UEC, UFG, UFRR, UNOP, UPCB, VIC); and also Global Biodiversity Information Facility (GBIF) (GBIF, 2017; GBIF, 2019). The data were rigorously verified for the presence of duplicated data and incoherencies related to geographical distribution, e.g., caused by typos in coordinates (HIJMANS e ELITH, 2015).

Due to the possibility of bias related to the occurrence of spatially autocorrelated points, frequently found in places with high incidence of collection, such as near herbaria and universities, the geographic occurrence data were spatially filtered (BORIA et al., 2014) by means of a subsampling, so that the analysis only considered occurrences at every $2.5 \mathrm{~km} \times 2.5 \mathrm{~km}$.

The altitude and 19 climatic variables obtained from WorldClim database (HIJMANS et al., 2005) at a resolution of 2.5 minutes $(\sim 5 \mathrm{~km})$ were considered for the present and future conditions as explanatory 
variables of the geographical distribution of this species.

Aiming to eliminate problems related to multicollinearity of the climatic and altitude explanatory variables (KHANUM et al., 2013), their Variance Inflation Factor (VIF) values were determined, and highly autocorrelated variable, i.e., those presenting a VIF above 10, were excluded.

The future climatic conditions for 2070 were based on the atmospheric circulation model HADGEM2-ES, by MET OFFICE, of the United Kingdom (UK), which is part of the Coupled Model Intercorporation Project Phase 5 (CMIP5). Two scenarios were considered based on assessments by Intergovernmental Panel on Climate Change (IPCC, 2013). The most optimistic scenario (RCP 4.5 with radiative forcing reaching 4.5 $\mathrm{W} / \mathrm{m}^{2}$ ) assumes the adoption of mitigation policies regarding the concentration of greenhouse gases on a global level. The most pessimistic one (RCP 8.5 with radiative forcing reaching $8.5 \mathrm{~W} / \mathrm{m}^{2}$ ) foresees extreme conditions considering that greenhouse gas emissions will continue to grow whether strategies to reduce them are not adopted.

The geographical distribution of this species was modeled by the Maximum Entropy algorithm (MaxEnt). For such, 100 pseudo-absences were generated for each observation of the species (LOBO e TOGNELLI, 2011) and randomly distributed within a $500 \mathrm{~km}$ radius. The data were subdivided into two groups: one was composed of $70 \%$ of the data and used for calibration (training) of adjustments, whereas the remaining $30 \%$ was used for validation (test) of adjustments, as suggested by Thuiller (2003). For each distribution of pseudo-absence, two rounds of calibration and test were carried out, totalling, six adjustments (three distributions of pseudo-absences $\mathrm{x}$ two calibration and test processes).

The performances of the adjustments were evaluated using the Total Sum of Squares TSS Statistics, which range from ${ }^{-1}$ to 1 . (ALLOUCHE et al., 2006). The better adjustment is closer to 1 . Then, the response curves were built between the climate suitability estimate and the most explanatory variables, according to the best performance adjustment. In order to reduce the uncertainties inherent to each adjustment, the current and future prediction for geographic distribution was determined by means of a consensus of adjustments with good performance (TSS > 0.4).

To quantify the impact of different climate change scenarios, a binary projection of the potential geographic extents of occurrence was projected for both current and future scenarios, in which estimates with occurrence probability higher than $50 \%$ were considered climatically suitable areas. After that, the projections were overlapped, stability areas were determined as those being potentially climatically suitable or not; whereas instability areas would no longer, or it would be, climatically suitable in the future.

All data were processed using the $\mathrm{R}$ statistical programming language with packages usdm (NAIMI, 2015), dismo (HIJMANS et al., 2015), raster (HIJMANS, 2015) and biomod2 (THUILLER et al., 2014).

\section{RESULTS}

Cedrela fissilis occurs widely across the Neotropical region (Figure 1). In terms of latitude, its distribution extends from the equatorial region $\left( \pm 10^{\circ} \mathrm{N}\right)$ to the south $\left( \pm 30^{\circ} \mathrm{S}\right)$ of the Tropic of Capricorn. As to longitude, its geographical distribution is cisandine, occurring in the range between 37 and $83^{\circ} \mathrm{W}$.

Regarding the distribution of this species in the American continent, there are data supporting its presence in most countries of South America and also in Central America, Panama, and Costa Rica. Nevertheless, its occurrence in most of the territory of Bolivia, Peru, Paraguay, and particularly in Brazil, is notable. In the latter, the species is distributed across most of its territory, occurring with higher density in the Southeast and South regions of the country.

Among the variables obtained to explain the C. fissilis geographical distribution, ten variables presented low multicollinearity (VIF $<10$ ), where four were related to temperature (Bio2, $\mathrm{Bio} 3, \mathrm{Bio} 4$, and Bio8), five to precipitation (Bio13, Bio14, Bio15, Bio18, and Bio19), in addition to altitude (Table 1).

The most explanatory variables in terms of the geographical distribution of the species, according to best adjustment $(\mathrm{TSS}=0.523)$, were isothermality (Bio3) and precipitation in the wettest month 


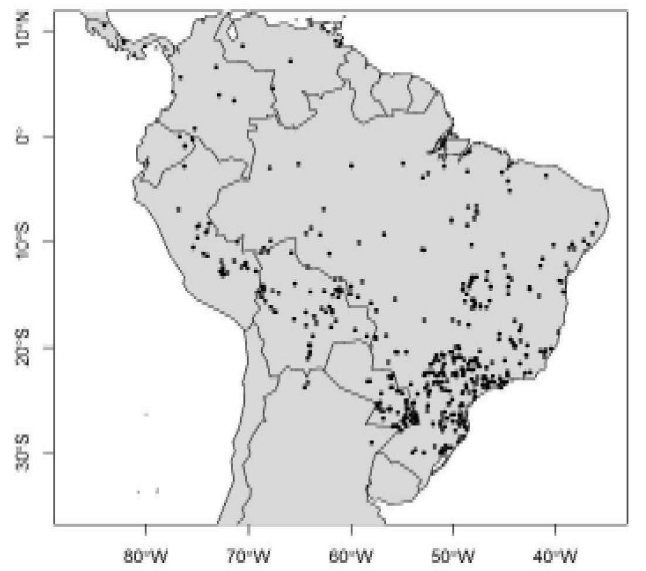

Figure 1 - Geographical distribution of C. fissilis (points) according to the records retrieved from the SpeciesLink and GBIF databases.

Figura 1 - Distribuição geográfica de C. fissilis (pontos) de acordo com os registros obtidos a partir dos bancos de dados do SpeciesLink e GBIF.

Table 1 - Climatic variables used to predict the geographical distribution of Cedrela fissilis after exclusion due to multicollinearity.

Tabela 1 - Variáveis climáticas utilizadas para a predição da distribuição geográfica de Cedrela fissilis após remoção da multicolinearidade.

\begin{tabular}{clc}
\hline Acronym & Description & VIF \\
\hline Alt & Altitude & 7.98 \\
Bio2 & Mean Diurnal Range & 2.82 \\
Bio3 & Isothermality & 9.23 \\
Bio4 & Temperature Seasonality & 9.73 \\
Bio8 & Mean temperature of the Wettest & \\
& Quarter & 6.43 \\
Bio13 & Precipitation of the Wettest Month & 4.80 \\
Bio14 & Precipitation of the Driest Month & 4.68 \\
Bio15 & Precipitation Seasonality & 2.96 \\
Bio18 & Precipitation of the Warmest Quarter & 2.79 \\
Bio19 & Precipitation of the Coldest Quarter & 3.89 \\
\hline
\end{tabular}
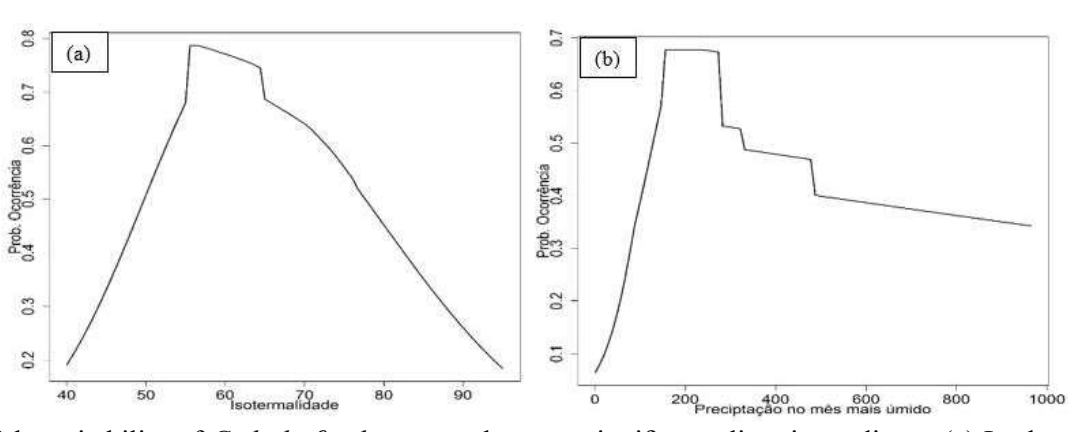

Figure 2 - Estimate of the suitability of Cedrela fissilis across the most significant climatic gradients. (a) Isothermality; (b) Precipitation in the wettest month.

Figura 2 - Estimativa de adequabilidade de Cedrela fissilis ao longo dos gradientes climáticos de maior significância. (a) Isotermalidade;

(b) Precipitação no mês mais úmido.

Revista Árvore 2019;43(3):e430306

(Bio13). In the case of Bio3, the species presented a higher estimate of suitability in areas where the isothermality ranged from $50 \%$ to $80 \%$. With values under or above this threshold, suitability is linearly reduced (Figure 2a). As to Bio13, the suitability estimate of the species was higher in the range between 150 and $500 \mathrm{~mm}$, presenting a sharp and linear drop below this range and having a constant decrease, however, with stability points, above this range (Figure 2b).

Regarding the current and future climate suitability of the species (Figure 3a, b, d), the most favorable areas for the occurrence of $C$. fissilis in Brazil are mainly in the South and Southeast region, however, to a lesser extent, in the Central-West and Northeast regions. The North region is relatively less favorable for the species occurrence.

In other countries of South America, the east and northeast of Paraguay and Argentina, respectively, as well as the surroundings of Andes in Bolivia and Peru, are the most favorable regions for the species occurrence in terms of climate. In Central America, although there are records of the species occurring in Panama and Costa Rica, the countries further to the north (Nicaragua, Honduras, Guatemala, Belize, and Mexico) presented a higher proportion of more favorable regions, which can also be observed to a lesser extent in Caribbean countries.

In future scenarios, the most optimistic projection (RCP 4.5) foresees a reduction of about $47 \%$ in climatic suitability for species occurrence (Figure $3 \mathrm{~b}$ ), considering a loss of about $50 \%$ and a gain of $6.55 \%$ (Table 2) in relation to the current favorable area. The areas that remained climatically suitable 


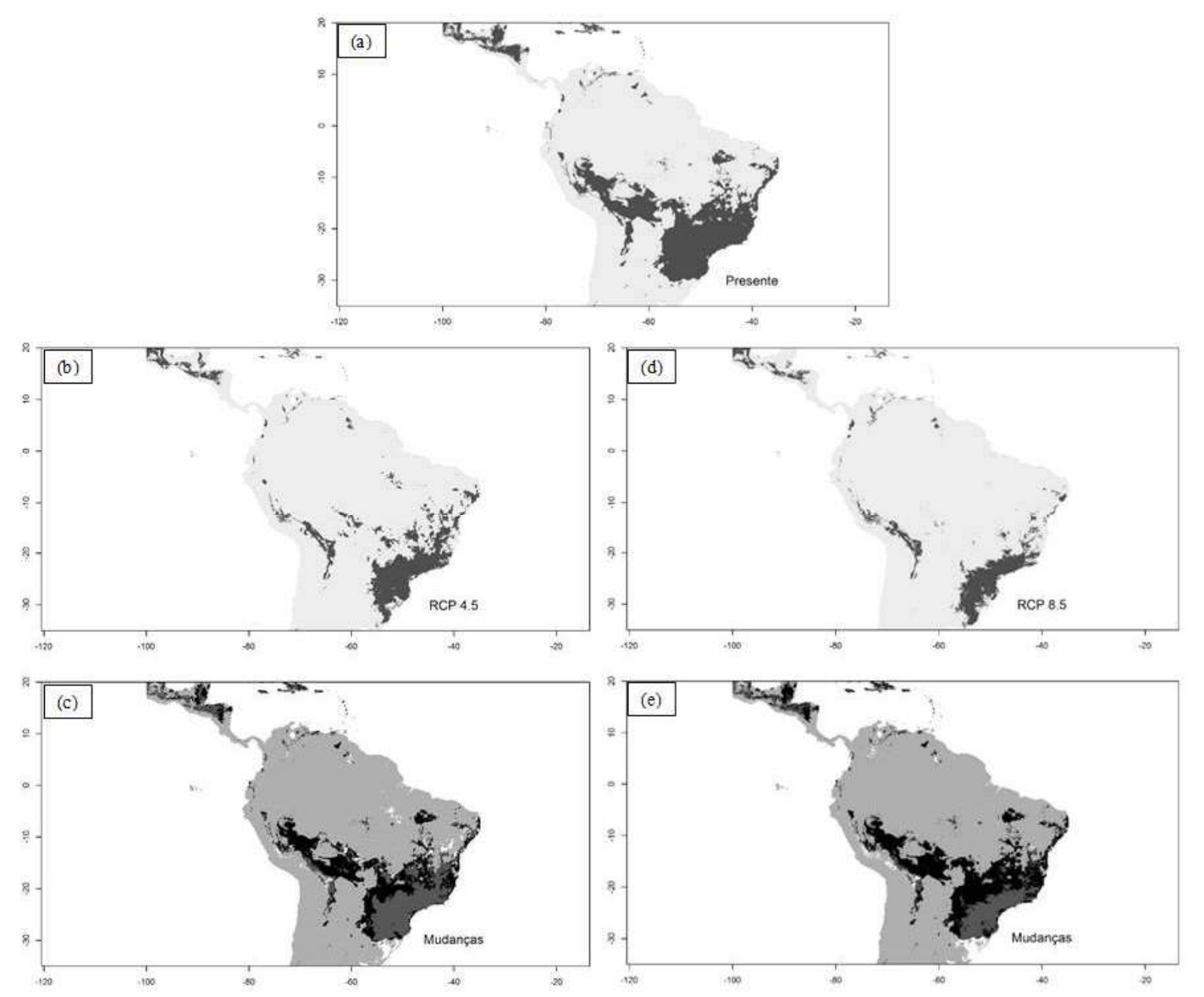

Figure 3 - Current (a) and future (2070) climatically suitable areas for occurrence of Cedrela fissilis, considering the optimistic (RCP 4.5) (b) and pessimistic (RCP 8.5) (d) scenarios with indication of the change patterns (c) and (e). In figures c and e, the dark gray color represents the stable areas, which present favorable climate and will continue to present in the future; the light gray color represents the stable areas not presenting favorable climate and that will remain as such in the future; the black color represents unstable areas that will no longer present favorable conditions for occurrence of the species; the white color represents unstable areas that will begin to present favorable climatic conditions for occurrence of the species.

Figura 3 - Áreas com adequabilidade climática para ocorrência geográfica de Cedrela fissilis para o presente (a) e futuro (2070), considerando o cenário otimista (RCP 4.5) (b) e pessimista (RCP 8.5) (d), com indicação dos padrões de mudanças (c) e (e). Nas figuras c e e, em cinza escuro são áreas estáveis, que apresentam o clima favorável e continuarão apresentando no futuro; cinza claro são áreas estáveis, que não apresentam o clima favorável e continuarão não apresentando no futuro; preto são áreas instáveis, que deixarão de apresentar condições favoráveis para a ocorrência da espécie; branco são áreas instáveis, que passarão a apresentar condições climáticas favoráveis para a ocorrência da espécie.

(Figure 3c, in dark gray) were mainly concentrated in the Southeast and South of Brazil. The losses were widely distributed across all the regions (Figure 3c, in black).

Of the total extent of favorable area for future species occurrence in this scenario $\left(2,704,475 \mathrm{~km}^{2}\right)$, about $88 \%$ will remain favorable for the species occurrence, even after climate changes. About $12 \%$ of the remaining areas will be composed of areas that are not currently favorable to this species, nevertheless these area will be climatically suitable for $C$. fissilis in the future. Among these areas, the southernmost region of Brazil and northeastern Uruguay are notable, as well as other smaller and sparse areas located in northern and northeastern Brazil, Venezuela, Bolivia, and Peru.

According to the pessimistic scenario ( $\mathrm{RCP}$ 8.5 ), a reduction of about $63 \%$ of climatic suitability area for the species is expected (Table 2). As for the optimistic scenario, the continent's regions that will

\section{Silf}

Revista Árvore 2019;43(3):e430306 
Table 2 - Impact of climate changes on the absolute (in $\mathrm{km} 2$ ) and relative (in \%) potential areas regarding climatic suitability for the occurrence of Cedrela fissilis in different climate change scenarios for 2070 .

Tabela 2 - Impacto de mudanças climáticas sobre as áreas potencias absolutas (em $\mathrm{km} 2$ ) e relativas (em \%), no que se refere à adequabilidade climática para a ocorrência de Cedrela fissilis, em diferentes cenários de mudanças climáticas para o ano de 2070 .

\begin{tabular}{lc}
\hline & \multicolumn{1}{c}{ Scenarios } \\
\cline { 2 - 2 } & $\begin{array}{c}\text { Optimistic } \\
\text { Pessimistic } \\
\text { (RCP } 8.5)\end{array}$ \\
\hline $\begin{array}{l}\text { Total area favorable to the occurrence of the species in the future }(\mathrm{km} 2) \\
\text { Stable area, currently favorable to the occurrence of the species and that }\end{array}$ & $2,704,475$ \\
will remain favorable in the future $(\mathrm{km} 2)$ & $2,372,925$ \\
$\begin{array}{l}\text { Stable area, currently unfavorable to the occurrence of the species and } \\
\text { that will remain unfavorable in the future }(\mathrm{km} 2)\end{array}$ & $1,873,075$ \\
Unstable area, currently favorable to the occurrence of the species and & $1,527,625$ \\
that will not remain favorable in the future $(\mathrm{km} 2)$ & $2,687,025$ \\
Unstable area, currently unfavorable to the occurrence of the species and & \\
that will become favorable in the future $(\mathrm{km} 2)$ & 331,550 \\
Climatic suitability area lost $(\%)$ & $3,532,325$ \\
Climatic suitability area gained $(\%)$ & 345,450 \\
Future climatic suitability area, in relation to the present $(\%)$ & -53.10 \\
\hline
\end{tabular}

be less impacted, in this sense, are mainly the South of Brazil, followed by the Southeast. In the rest of the continent, the reduction will be more pronounced (Figure 3e).

\section{DISCUSSION}

Although Cedrela fissilis reaches Central America, it is restricted to areas where isothermality is between $50 \%$ and $80 \%$ and without long periods of low rainfall. Isothermality values above $80 \%$ indicate that daily temperature variation is relatively close to annual temperature variation. This pattern can occur in environments tending to tropicality, especially in regions near the Equator. This pattern occurs because, in these places, both daily and annual variation have small amplitudes. On the other hand, isothermality values below $50 \%$ suggest locations where the daily temperature range is higher than the annual.

According to the other species of Cedrela genus, C. fissilis is the species with the widest range of geographic distribution throughout South and Central America (KÖCKE, 2015). This fact may be associated with the species' ability to occur in different vegetation formations, being peculiar in dry forests, subsistent in open fields and even in Cerrado (RIZZINI, 1971). With regard to edaphic conditions, this species has a preference for well-drained clay and loam soils with high water retention from the bottom of valleys and along rivers and lowlands, however, not developing properly in poorly drained and shallow soils, or in soils with shallow groundwater table (INOUE et al., 1984; REITZ, 1984). The high capacity of physiological adaptation to the light conditions (PINHEIRO et al., 1990), the deciduous behavior, which allows adaptation to environments with water deficit (MUELLNER et al., 2010), and also the high dispersion capacity of propagules (CARVALHO, 2003) are autecological aspects that may explain the wide geographical distribution of this species.

Based on the results found, our study observed that, despite its wide geographical distribution, $C$. fissilis is more present across the entire Atlantic Forest Biome, mainly covering the South and Southeast of Brazil. This region has temperate and subtropical climate, from mild to hot summers and without long periods of drought. This pattern can be explained by the fact that greater climatic suitability for the species and greater historical climate stability are observed in this region. Thus, providing refuge areas for C. fissilis during climate cycles that affected other regions more drastically (INOUE et al., 1984; CARNAVAL et al., 2009). On the other hand, the probability of occurrence is lower in other biomes, such as Cerrado and Amazon. The predominant climate types of these regions are Aw, Am, and Af, according to the Köppen classification; overall, these biomes present the average temperature of the coldest month exceeding $18^{\circ} \mathrm{C}$.

Regarding the impacts of climate change, projections of climatically suitable areas for this species in future climate scenarios indicate that the

\section{Revista Árvore 2019;43(3):e430306}


northernmost and lower elevation regions will be less favorable to the occurrence of $C$. fissilis (Figure 3 ). Notably, the favorable area for $C$. fissilis will be reduced in regions of Cerrado Biome and the northern portion of Atlantic Forest, while the more southern and high altitude regions, especially those located in the subtropical portion of Atlantic Forest, will be more climatically suitable for the species. Similarly, Estrada-Contreras et al. (2016) could find in several scenarios of future climate change for Mexico, that the occurrence of $C$. odorata L. will be favored, especially in high altitude regions, such as the mountain ranges. Silva (2016), in projecting the climate suitability of Ilex paraguariensis A.St.-Hil. and Mimosa scabrella Benth. in climate change scenarios in Brazil, has similarly verified that regions with high altitudes will tend to be more favorable for the species development, highlighting the regions with typically humid temperate climate, which is also observed for C. fissilis.

Forecasts for both climate change scenarios indicate that part of Southern Brazil, where the Pampa Biome occurs - which is not currently climatically suitable for C. fissilis - will present favorable conditions for the species in the future.

In general, the displacement of plant species towards colder regions of higher latitude and altitude has been observed with the recent increase in temperature in temperate regions (WALTHER et al., 2002). In addition, species that are heat- or droughttolerant and adapted to fire will be favored in regions subject to reduced rainfall, which will consequently decrease species richness in most biomes (WILLIAMS et al., 2007).

The impact of climate change on the occurrence of species is part of a process associated with evolutionary history regarding anthropic action, so that forecasting the ability of species to adjust their favorable areas of occurrence is highly complex. In the case of $C$. fissilis, it is key to understand the impacts of anthropic nature, such as forest fragmentation, because the species' populations in Brazil and other countries are threatened by deforestation and selective exploitation (STEINER, 2014).

The impacts of climate change on the geographic occurrence of $C$. fissilis will not take place homogeneously in the territory it occupies. Thus, mitigation measures aimed at the conservation of the species should be analyzed according to the type of impact observed. In this sense, the following possible alternatives are suggested:

a) Stable areas, which will remain in the appropriate climate for species, such as those in Southern and Southeastern Brazil, should be considered strategic for in situ conservation by the creation and expansion of protected areas;

b) Unstable areas that will no longer have a favorable climate in the future, such as those in Central Brazil and the northern portion of Atlantic Forest, should be considered strategic for genetic rescue and the establishment of germplasm banks;

c) Unstable areas that will have a favorable future climate, such as those in southernmost region of Brazil, should be considered as potential new areas of ecological and silvicultural interest;

d) For all circumstances considered, the sensitivity of $C$. fissilis to the moth Hypsipyla grandella, when cultivated as pure stands, should not be ignored (CUSATIS et al., 2018). Therefore, planting in the form of consortia or forest enrichment in recovery programs or managed forests is recommended (CUSATIS et al., 2018).

\section{CONCLUSION}

Cedrela fissilis is widely geographically distributed, occurring in South and Central America, especially in Brazil, Paraguay, Bolivia, and Peru. The occurrence of this species was observed to be more related to regions where climatic conditions presented intermediate values of isothermality $(\sim 60 \%)$ and the wettest month presents rainfall of at least $150 \mathrm{~mm}$.

The climatically suitable area for the potential species occurrence will be reduced in future scenarios across South and Central America, and this is expected to be more pronounced in the pessimistic climate projection by IPCC. At the same time, certain areas, especially those located in the southernmost region of Brazil and northeastern Uruguay, will become climatically more favorable for the species occurrence.

\section{ACKNOWLEDGEMENTS}

To FAPESC, for the scholarship granted to the first author and support by means of PAP/UDESC.

Revista Árvore 2019;43(3):e430306

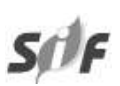


To CNPq, for the research fellowship granted to the second and third authors. To herbaria ALCB, ASE, BCTw, BHCB, BOTU, CEN, CEPEC, CGMS, CNMT, CPAP, CRI, DVPR, EAC, EAFM, EFC, ESA, EVB, F, FPR-Colombia, FPS, FUEL, Funed-Pol, FURB, G, HAS, HbVirtFlBras, HCF, HDCF, HDJF, HEPH, HERBAM, HPAN, HPL, HUCPE, HUCS, HUEFS, HUEM, HUESB, HUFSJ, HUTO, HVASF, HVAT, IAC, INPA, IRAI, JPB, MAC, MBM, MBMLHerbario, MO, MPUC, NHM-London-BOT, NY, PACA-AGP, RON, SinBiota, SJRP, SP, SPF, SPFw, SPSF, UB, UEC, UFG, UFRR, UNOP, UPCB, VIC, for lending the data via SpeciesLink.

\section{REFERENCES}

Allouche O, Tsoar A, Kadmon R. Assessing the accuracy of species distribution models: prevalence, kappa and the true skill statistic (TSS). Journal of Applied Ecology. 2006;43(6):1223-1232.

Boria RA, Olson LE, Goodman SM, Anderson RP. Spatial filtering to reduce sampling bias can improve the performance of ecological niche models. Ecological Modelling. 2014;275(C):73-77.

Carnaval AC, Hickerson MJ, Haddad CFB, Rodrigues MT, Moritz C. Stability predicts genetic diversity in the Brazilian Atlantic Forest hotspot. Science. 2009;323(5915):785-789.

Carvalho PER. Espécies arbóreas brasileiras. Brasília: Embrapa Informação Tecnológica; 2003. 1035p.

CRIA. SpeciesLink. [acessado em: 9 jun. de 2017]. Disponível em: http://splink.cria.org.br/

Estrada-Contreras I, Equihua M, Laborde J, Meyer EM, Sánchez-Velásquez LR. Current and future distribution of the tropical trees Cedrela odorata L. in Mexico under climate change scenarios using MaxLike. PloS One. 2016;11(10):e0164178.

Cusatis AC, Martinez DT, Silva LD, Higa AR. Survival and growth of Cedrela fissilis (Vell.) in mixed species forest plantations. Scientia Forestalis. 2018;46(119):357-366.

Field, CB, Barros, V, Dokken, DJ, Mach, KJ, Mastrandrea, MD, Bilir TE, Chatterjee M, Ebi KL, Estrada YO, Genova RC, Girma B, Kissel ES, Levy AN, MacCraken S, Mastrandrea PR, White
LL. Climate change 2014: impacts, adaptation, and vulnerability. Volume I: Global and Sectoral Aspects. Contribution of Working Group II to the Fifth Assessment Report of the Intergovernmental Panel on Climate Change. Cambridge University Press, Cambridge and New York; 2014

Garcia MG, Silva RS, Carniello MA, Veldman JW, Rossi AA, Oliveira LO. Molecular evidence of cryptic speciation, historical range expansion, and recent intraspecific hybridization in the Neotropical seasonal forest tree Cedrela fissilis (Meliaceae). Molecular Phylogenetics and Evolution. 2011;61(3):639-649.

GBIF - Global Biodiversity Information Facility. Cedrela fissilis data. [access in: 9 jun. 2017]. Available at: https://www.gbif.org/ species/7107974

GBIF - Global Biodiversity Information Facility. GBIF Occurrence Download [access in 19 April 2019. Available at: https://doi.org/10.15468/ d1. $5 \mathrm{gb} 3 \mathrm{~d} 2$

Hijmans RJ, Cameron SE, Parra JL, Jones PG, Jarvis A. Very high resolution interpolated climate surfaces for global land areas. International Journal of Climatology. 2005;25(15):1965-1978.

Hijmans RJ. raster: Geographic Data Analysis and Modeling. R package version 2.3-40, 2015. [access in: 9 jun. 2017]. Disponível em: https:// cran.r-project.org/package $=$ raster

Hijmans RJ., Phillips S, Leathwick J, Elith J. dismo: Species Distribution Modeling. R package version 1.0-12, 2015. [access in: 9 jun. de 2017]. Available at: https://cran.r-project.org/web/ packages/dismo/index.html

Hijmans RJ, Elith J. Species distribution modeling with R. 2015. [access in: 9 jun. de 2017]. Available at: https://cran.r-project.org/web/packages/dismo/ vignettes/sdm.pdf

Inoue MT, Roderjan CV, Kuniyoshi YS. Projeto Madeira do Paraná. Curitiba: FUPEF/UFPR, 1984. 260p.

IPCC. Summary for Policymakers. In: Climate Change 2013: The Physical Science Basis. Contribution of Working Group I to the Fifth 
Assessment Report of the Intergovernmental Panel on Climate Change [Stocker, T.F., D. Qin, G.-K. Plattner, M. Tignor, S. K. Allen, J. Boschung, A. Nauels, Y. Xia, V. Bex and P.M. Midgley (eds.)]. Cambridge University Press, Cambridge, United Kingdom and New York, NY, USA; 2013.

International Union for Conservation of Nature and Natural Resources (IUCN). IUCN Red List of Threatened Species. 2013. Versão 2013.2. [access in: 4 may 2017]. Available at: http://www.iucnredlist.org

Khanum R, Mumtaz AS, Kumar S. Predicting impacts of climate change on medicinal asclepiads of Pakistan using Maxent modeling. Acta Oecologica. 2013;49:23-31.

Köcke AV. Spatio-temporal evolution of Cedrela (Meliaceae) [tese]. Frankfurt: Universidade Johann Wolfgang Goethe de Frankfurt; 2015.

Lobo JM, Tognelli MF. Exploring the effects of quantity and location of pseudo-absences and sampling biases on the performance of distribution models with limited point occurrence data. Journal for Nature Conservation. 2011;19(1):1-7.

Muellner AN, Pennington TD, Koecke AV, Renner SS. Biogeography of Cedrela (Meliaceae, Sapindales) in Central and South America. American Journal of Botany. 2010;97(3):511-518.

Naimi B. USDM: Uncertainty Analysis for Species Distribution Models. R package version 1.1-15, 2015. [access in: 9 jun. de 2017]. Available at: https://cran.rproject.org/web/packages/usdm/index.html

Pinheiro AL, Maragon LC, Paiva GLRM. Características fenológicas do Cedro (Cedrela fissilis Vell.) em Viçosa, Minas Gerais. Boletim de Pesquisa Florestal. 1990;21:21-26.

Randin CF, Engler R, Normand S, Zappa M, Zimmermann NE, Pearman PB, Vittoz P, Thuiller W, Guisan A. Climate change and plant distribution: local models predict high-elevation persistence. Global Change Biology. 2009;15(6):1557-1569.
Reitz JR. Meliaceae. Itajaí: Flora Ilustrada Catarinense; 1984. 140p.

Rizzini CT. Árvores e madeiras úteis do Brasil: manual de dendrologia brasileira. São Paulo: Edgard Blücher; 1971. 294p.

Silva MAF. Nichos bioclimáticos e predição do impacto de mudanças climáticas sobre as distribuições geográficas de Ilex paraguariensis A.St.-Hil. e Mimosa scabrella Benth. [dissertação] Lages: Universidade do Estado de Santa Catarina; 2016.

Steiner F. Diversidade genética e análise da paisagem de espécies arbóreas da Floresta Estacional Decidual [tese]. Brasília: Universidade de Brasília; 2014.

Thuiller W. BIOMOD - optimizing predictions of species distributions and projecting potential future shifts under global change. Global Change Biology. 2003;9(10):1353-136.

Thuiller W, Lavorel S, Araújo MB. Niche properties and geographical extent as predictors of species sensitivity to climate change. Global Ecology and Biogeography. 2009;14(4):347-357.

Thuiller W, Georges D, Engler R, Breiner F. biomod2: ensemble platform for species distribution modeling. $\mathrm{R}$ package version 3., p. 1-64, 2014. [Access in: 9 jun de 2017]. Disponível em: https://cran.r-project.org/ web/packages/biomod2/index.html

Walther GR, Post E, Convey P, Menzel A, Parmesan C, Beebee TJC, Fromentin J-M, Hoegh-Guldber O, Bairlein F. Ecological responses to recent climate change. Nature. 2002;416(6879):389-395.

Webber BL, Scott JK. Rapid global change: implications for defining natives and aliens. Global Ecology and Biogeography. 2012;21(3):305-311.

Williams JW, Jackson ST, Kutzbach JE. Projected distributions of novel and disappearing climates by 2100 AD. Proceedings of National Academy of Sciences (PNAS). 2007;104(14):5738-5742. 